\begin{tabular}{|c|c|c|}
\hline & $\begin{array}{l}\text { Jurnal Teknologi Kimia Unimal } \\
\text { http://ft.unimal.ic.id/teknik_kimia/jurnal }\end{array}$ & $\begin{array}{l}\text { Jurnal } \\
\text { Teknologi } \\
\text { Kimia } \\
\text { Unimal }\end{array}$ \\
\hline
\end{tabular}

\title{
KINETIKA HIDROLISA KULIT PISANG KEPOK MENJADI GLUKOSA MENGGUNAKAN KATALIS ASAM KLORIDA
}

\author{
Novi Sylvia ${ }^{1}$, Meriatna ${ }^{1}$, Haslina ${ }^{1}$ \\ ${ }^{1}$ Jurusan Teknik Kimia, Fakultas Teknik, Universitas Malikussaleh \\ Laboratorium Teknik Kimia, Jl. Batam No. 2, Bukit Indah, Lhokseumawe 24353 \\ e-mail: nxsylvia@gmail.com
}

\begin{abstract}
Abstrak
Kulit pisang merupakan bahan buangan (limbah buah pisang) yang cukup banyak jumlahnya. Salah satu kandungan kulit pisang kepok adalah pati atau karbohidrat. Karbohidrat dapat dikonversi menjadi gula dengan metode hidrolisis. Penelitian ini bertujuan untuk mengkonversi pati atau karbohidrat dari kulit pisang kepok dan mencari kinetika reaksi hidrolisa tersebut yang, juga menentukan kecepatan reaksi serta energi aktivasi. Proses hidrolisis menggunakan katalis HCI dilakukan dalam labu yang dilengkapi dengan pengaduk, serta dipanaskan di atas pemanas dengan menvariasiakan suhu $\left(80,85,90,95\right.$ dan $\left.100^{\circ} \mathrm{C}\right)$ dan waktu reaksi (10,20,30,40,50 dan 60 menit).Hasil penelitian menunjukkan bahwa kinetika reaksi hidrolisis kulit pisang kepok menggunakan $\mathrm{HCl}$ merupakan reaksi orde satu semu, dengan konstanta kecepatan reaksi untuk masing-masing temperatur adalah 0.003533, $0.004022,0.004461,0.004571$ dan 0.004645 1/menit, dengan energi aktivasi $14,751 \mathrm{kj} / \mathrm{mol}$.
\end{abstract}

Kata kunci $\quad$ : kulit pisang, pati, glukosa, hidrolisis, katalisator HCI

\section{Pendahuluan}

Di Indonesia tanaman pisang masih dapat tumbuh dengan subur di daerah pegunungan hingga ketinggian 2.000 meter dengan udara dingin. Tanaman pisang tahan di musim kering, karena batangnya banyak mengandung air (kurang lebih $80-90 \%)$. Tetapi jangan diharapkan pisang dapat tumbuh dengan baik di daerah kering (curah hujan sedikit dan tanah menjadi kering). Di daerah banjir, tanaman pisang akan sulit tumbuh dengan baik. Tanaman pisang akan tumbuh subur walaupun curah hujannya tinggi, tetapi bebas banjir yang diimbangi dengan air 50 
cm dari atas permukaan, (Munadjim,1983).Pisang merupakan tumbuhan monokotil yang termasuk dalam familia Musaceae. Pohonnya memiliki tinggi dua hingga sembilan meter, akar rizoma berada dalam tanah dan pelepahnya terdiri dari lembaran daun dan mahkota daun tempat munculnya bakal buah. Pisang merupakan buah klimaterik yang artinya memiliki fase perkembangan, dengan meningkatnya ukuran buah dan meningkatnya kadar karbohidrat yang terakumulasi dalam bentuk pati. Pertumbuhan terhenti saat buah telah benar-benar ranum dan fase pematangan buah terhambat. Selama fase pematangan, kekerasan buah menurun, pati berubah menjadi gula, warna kulit berubah dari hijau menjadi kuning dan kekelatan pada buah hilang, berkembang menjadi flavor dengan karakteristik yang khas.Salah satu alternatif dari pemanfaatanpisang yaitu dapat diolah menjadi pati.Masyarakat pedesaan memanfaatkan kulit pisang sebagai pakan ternak. Padahal kulit pisang mengandung 18,90 gr karbohidrat pada setiap 100 gr bahan. (Susanto dan Saneto,1994). Untuk lebih mengoptimalkan fungsinya, pisang dapat dibuat menjadi bahan lain yang lebih bermanfaat antara lain glukosa. Buah pisang mengandung pati yang bisa dipisahkan menjadi glukosa dengan cara hidrolisis. Proses hidrolisis limbah pisang dilakukan dengan cara mereaksikan pati pisang dengan air berlebih menggunakan katalisator HCL.

Kulit pisang masih belum mendapatkan penanganan yang cukup karena pada kulit pisang masih mengandung pati, protein, dan serat yang tinggi ( Stover dkk, 1987). Masalah yang sering dihadapi pada industri kimia adalah pemanfaatan bahan-bahan tidak berguna yang murah menjadi bahan-bahan yang lebih berguna danbernilai tinggi. Pada pada umumnya tebal kulit pisang adalah 41 bagian dari buahnya, oleh karena itu diperlukan pemikiran usaha untuk memanfaatkannya.

Mengingat pentingnya data kinetika dalam perancangan reaktor diperlukan data kinetika reaksi. Untuk itu pada penelitian ini, peneliti mencoba menghitung konstanta reaksi ( konstanta kecepatan reaksi dan orde terhadap pereaksi) hidrolisis kulit pisang kepok.Beberapa penelitian yang telah dilakukan sebelumnya dalam mengkaji kinetika reaksi hidolisa menjadi glukosa antara lain yang dilakukan oleh Yuniwati dkk (2011), pada kinetika reaksi hidrolisis pati pisang tanduk dengan katalisator asam klorida pada konsentrasi 0,5 $\mathrm{N}$ sampai 2,5 
$\mathrm{N}$, perbandingan pati dan air $1 \mathrm{gr}$ : $100 \mathrm{ml}$ konversi glukosa tertinggi $48 \%$ diperoleh pada konsentrasi $\mathrm{HCl}$ 2,5 $\mathrm{N}$ dengan waktu reaksi 60 menit dan temperatur reaksi $90{ }^{0} \mathrm{C}$ diperoleh nilai konstanta kecepatan reaksi $\mathrm{k}=0.007383 \mathrm{~s}^{-}$ 1. Persamaan Arhenius yang diperoleh $\mathrm{k}=1.0106 \mathrm{e}^{-1844 / \mathrm{RT}}$, dengan temperatur reaksi (T) dalam Kelvin. Artati dkk.,( 2006), juga meneliti tentang pengaruh konsentrasi asam terhadap hidrolisa pati pisang, hasil penelitian menunjukkan, konstanta kecepatan reaksi dipengaruhi oleh konsentrasi HCI, semakin besar konsentrasi HCI, semakin besar pula konstanta kecepatanreaksi. Herman dkk., (2004), meneliti tentang kinetika reaksi hidrolisis minyak sawit dengan katalisator asam klorida yaitu, Adanya perbedaan nilai k dan orde reaksi pada penelitian ini dengan penelitian yang lain, disebabkan perbedaan dalam perhitungannya. Dimana pada penelitian yang lain nilai ini diasumsikan, sedangkan pada penelitian ini dihitung. Sedangkan perbedaan pada konversi yang dicapai, kemungkinan disebabkan perbedaan jenis dan aktifitas dari katalisator yang digunakan.Dewi (2005), meneliti tentangkinetika reaksi hidrolisa kulit durian menjadi glukosa dengan katalisator $\mathrm{HCl}$ pada tangki berpengaduk". menunjukkan, hasil terbaik dalam penelitian ini adalah konversi terbesar kulit durian menjadi glukosa sebesar $0,072 \mathrm{mg} / \mathrm{ml}$ diperoleh pada suhu $95^{\circ} \mathrm{C}$ dengan waktu 80 menit. Dewati (2005), meneliti tentang hidrolisa pati ubi jalar menjadi glukosa dengan katalisator asam sulfat. Hasil penelitian dipengaruhi oleh suhu, waktu hidrolisa, dan konsentrasi katalisator merupakan orde satu semu. Beranjak dari penelitianpenelitian di atas, langkah selanjutnya penulis akanmenganalisakinetika reaksi hidrolisis kulit pisang kepokmenjadi glukosa dengan menggunakan katalis asam klorida.

\section{Tinjauan Pustaka}

Pati merupakan homopolimer glukosa dengan ikatan $\alpha$-glikosidin. Berbagai macam pati tidak sama sifatnya, tergantung dari panjang rantai $\mathrm{C}$-nya, serta lurus atau bercabang rantai molekulnya. Pati terdiri dari dua fraksi yang dapat dipisahkan dengan air panas. Fraksi terlarut disebut amilosa dan fraksi tidak larut disebut amilopektin. Amilosa mempunyai struktur lurus dengan ikatan $\alpha-(1,4)$ - 
glukosa, sedangkan amilopektin mempunyai cabang dengan ikatan $\alpha-(1,4)$-Dglukosa sebanyak 4-5\% dari berat total (Winarno, 1981).Hidrolisis pati terjadi antara reaktan pati dengan reaktan air, reaksi ini adalah orde satu karena reaktan air yang dibuat berlebih, sehingga perubahan reaktan dapat diabaikan. Reaksi hidrolisis pati dapat menggunakan katalisator ion $\mathrm{H}^{+}$yang dapat diambil dari asam. Reaksi yang terjadi pada hidrolisis pati adalah sebagai berikut :

$$
\left(\mathrm{C}_{6} \mathrm{H}_{10} \mathrm{O}_{5}\right) \mathrm{x}+\mathrm{x} \mathrm{H} \mathrm{H}_{2} \mathrm{O} \longrightarrow \mathrm{x} \mathrm{C}_{6} \mathrm{H}_{12} \mathrm{O}_{6}
$$

\section{Kinetika Reaksi}

Reaksi hidrolisis pada umumnya menggunakan pereaksi berupa air yang jumlahnya dibuat berlebihan dapat dituliskan sebagai:

$$
\mathrm{r}_{\mathrm{A}}=-\frac{\mathrm{dCA}}{\mathrm{dt}}=\mathrm{kC}_{\mathrm{A}}{ }^{\mathrm{m}} \mathrm{C}_{\mathrm{B}}{ }^{\mathrm{n}}
$$

Dengan:

$\mathrm{C}_{\mathrm{A}}=$ Konsentrasi selulosa

$\mathrm{C}_{\mathrm{B}}=$ Konsentrasi air

$\mathrm{r}_{\mathrm{A}}=$ kecepatan berkurangnya $\mathrm{A},(\mathrm{gmol} /($ Lmenit $))$

$\mathrm{t}=$ waktu reaksi, menit

$\mathrm{m}, \mathrm{n}=$ order reaksi

Dengan jumlah air yang berlebihan, maka bisa dianggap konsentrasi air tetap selama reaksi berlangsung, maka persamaan menjadi:

$\mathrm{r}_{\mathrm{A}}=\underset{\mathrm{dt}}{\mathrm{d} \mathrm{C}_{\mathrm{A}}}=\mathrm{k}^{\prime} \mathrm{C}_{\mathrm{A}}^{\mathrm{m}}$

Dimana $\mathrm{kC}_{\mathrm{B}}{ }^{\mathrm{n}} \mathrm{n}$ dianggap konstan $=\mathrm{k}$ '

Apabila $\mathrm{m}=1$ maka

$r_{\mathrm{A}}=-\frac{\mathrm{dC}_{\mathrm{A}}}{\mathrm{dt}}=\mathrm{k}^{\prime} \mathrm{C}_{\mathrm{A}}$ 
Hasil integrasi dari waktu $\mathrm{t}=0$ hingga $\mathrm{t}=$ tdengan $\mathrm{C}_{\mathrm{A}}=\mathrm{C}_{\mathrm{A} 0}$ hingga $\mathrm{C}_{\mathrm{A}}=\mathrm{C}_{\mathrm{A}}$ adalah sebagai berikut:

$-\operatorname{In} \frac{\mathrm{C}_{\mathrm{A}}}{\mathrm{C}_{\mathrm{A} 0}}=\mathrm{kt}$

Apabila perbandingan A yang bereaksi dengan A mula-mula dinyatakan sebagai konversi (x)maka dapat dinyatakan :

$\mathrm{C}_{\mathrm{A}}=\mathrm{C}_{\mathrm{A} 0}-\mathrm{C}_{\mathrm{A} 0} \mathrm{x}=\mathrm{C}_{\mathrm{A} 0}(1-\mathrm{x})$

$\frac{\mathrm{C}_{\mathrm{A}}}{\mathrm{C}_{\mathrm{A} 0}}=1-\mathrm{x}$

Maka persamaan 6 dapat dinyatakan:

$-\ln (1-\mathrm{x})=\mathrm{kt}$

Apabila dibuat grafik hubungan-ln $\frac{\mathrm{C}_{\mathrm{A}}}{\mathrm{C}_{\mathrm{A} 0}}$ versus $\mathrm{t}$ atau $-\ln (1-\mathrm{x})$ versus akan mendekati garis gradien dari garis tersebut. Tetapi, apabilabukan garis lurus maka dicoba orde reaksi yanglain misalnya reaksi orde 2 .Apabila $\mathrm{m}=2$ maka

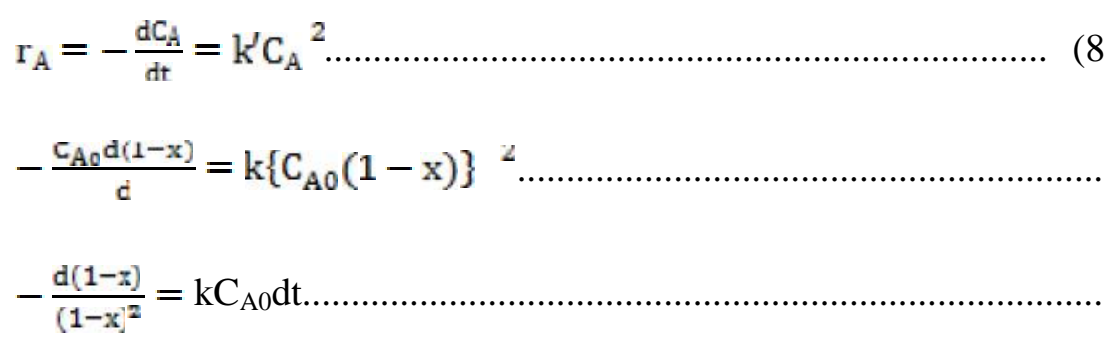

Hasil integrasi dari waktu $\mathrm{t}=0$ hingga $\mathrm{t}=\mathrm{t}$ dengan $\mathrm{x}=0$ hingga $\mathrm{x}=\mathrm{x}$ adalah sebagai berikut:

$\frac{\mathrm{x}}{(1-\mathrm{x})}=\mathrm{kC}_{\mathrm{AO}} \mathrm{t}$

Apabila dibuat grafik hubungan $\frac{\mathrm{x}}{(1-\mathrm{x})}$ versus $\mathrm{C}_{\mathrm{A} 0} \mathrm{t}$ maka akan mendekatigaris lurus dan konstanta kecepatanreaksinya adalah gradien dari garistersebut. Apabila tidak merupakan garislurus dicoba orde lain. 
Kesesuaian data penelitian denganpersamaan kecepatan reaksi maupun nilai kbisa dihitung dengan metode least square.Pada umumnya nilai konstanta kecepatanreaksi dipengaruhi oleh faktor tumbukan,energi aktivasi dan suhu reaksi yang bisadinyatakan dalam bentuk persamaanmatematis sesuai persamaan Arhenius:

$\mathrm{k}=\mathrm{A} \mathrm{e}^{-\frac{\mathrm{B}}{\mathrm{KT}}}$

dimana:

$\mathrm{k}=$ konstanta kecepatan reaksi

$A=$ frekuensi tumbukan

$\mathrm{T}=$ suhu reaksi, $\mathrm{K}$

$\mathrm{E}=$ tenaga aktivasi,cal/gmol

$\mathrm{R}=$ tetapan gas,cal/(gmol K)

Persaman tersebut menunjukkan bahwakonstanta kecepatan reaksi akan semakinbesar dengan semakin berkurangnya energiaktivasi dan semakin besarnya suhu. Energiaktivasi dapat diperkecil denganmenggunakan katalisator. Sedangkan suhureaksi dibuat tinggi denganmempertimbangkan ketahanan bahan serta keseimbangan reaksi (levenspiel,1972).

\section{Metode Penelitian}

Penelitian dilakukan melalui tigatahap yaitu tahap persiapan bahan (pembuatan pati), tahap kedua adalah proses hidrolisis dan tahap ketiga adalah analisis hasil. Kulit pisang di bersihkan dari kotoran kemudian dicuci bersih lalu diiris kecil - kecil lalu dimasukkan kedalam oven untuk dikeringkan padasuhu $105{ }^{\circ} \mathrm{C}$ sampai kering kemudian di haluskan kulit kepokyang sudah kering dengan cara diblender hingga berbentuk serbuk. Kemudian diAyak serbuk kulit pisang pada ayakan 80 mesh. Pati sebanyak 25 gr dimasukan ke dalam larutan $\mathrm{HCl}$ (Asam klorida) dengan konsentrasi 2,5 $\mathrm{N}$ berfungsi sebagai katalisator dan air 
sebagai pereaksi. Reaksi dijalankan dalam rangkaian alat hidrolisis yang dapat dilihat pada Gambar 1. Reaksi dilakukan pada suhu 80, 85, 90, 95 dan $100^{\circ} \mathrm{C}$ yang divariasikan. Setiap selang waktu 10, 20, 30, 40, 50 dan 60 menit diambil sampel untuk dianalisis.

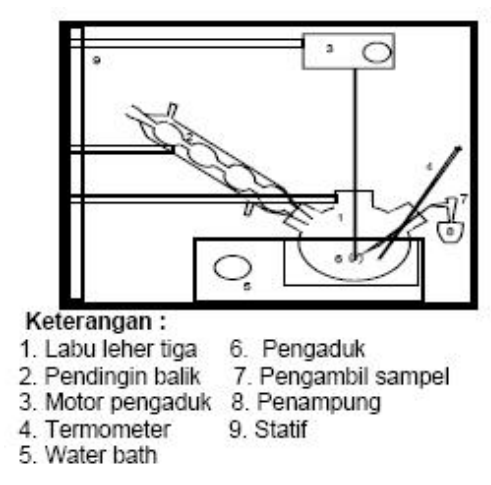

Gambar 1. Rangkaian Alat Hidrolisis

\section{Hasil dan Diskusi}

Hidrolisis adalah reaksi kimia antara air dengan suatu zat lain yang menghasilkan satu zat baru atau lebih. Karena reaksi antara pati dengan air berlangsung sangat lambat, maka untuk memperbesar kecepatan reaksinya diperlukan penambahan katalisator. Penambahan katalisator ini berfungsi untuk memperbesar keaktifan air, sehingga reaksi hidrolisis tersebut berjalan lebih cepat. Salah satu katalisator yang sering digunakan adalah asam klorida.

Untuk mendapatkan kinetika reaksi pada hidrolisa kulit pisang kepok ini terlebih dahulu dilakukan tahap analisa kadar glukosa, dengan hukum stoikiometri maka dapat dihitung jumlah pati bereaksi dengan begitu mol bereaksi terhadap mol mula-mula yang disebut dengan konversi pun diperoleh.Berikut ditampilkan hasil penelitian pada tabel 1. maka dapat diperolah hasil kadar glukosa (gr) dan konversi (x) untuk konsentrasi 2,5 N. 
Novi Sylvia dkk / Jurnal Teknologi Kimia Unimal 4 : 2 (November 2015) 51 - 65

Tabel 1 Kadar glukosa yang dihasilkan dari 25 gr pati dalam $1500 \mathrm{ml}$ air pada setiap satuan waktu, temperatur dengan konsentrasi HCL 2,5 N.

\begin{tabular}{|c|c|c|c|c|c|c|c|c|}
\hline \multirow{2}{*}{$\begin{array}{c}\text { Katalis } \\
(\mathrm{HCl})\end{array}$} & $\begin{array}{c}\text { Temperatur } \\
\left({ }^{\circ} \mathrm{C}\right)\end{array}$ & \multicolumn{6}{|c|}{ Kaktu (menit) } \\
\cline { 3 - 8 } & & 10 & 20 & 30 & 40 & 50 & 60 \\
\cline { 2 - 8 } & 80 & 5.28 & 6 & 6,96 & 7,2 & 7,95 & 8,45 \\
\cline { 2 - 8 } & 85 & 6 & 6,96 & 7,2 & 7,95 & 8.2 & 9,2 \\
\cline { 2 - 8 } $2,5 \mathrm{~N}$ & 90 & 7,95 & 8.2 & 8.95 & 9.45 & 9.95 & 10.325 \\
\cline { 2 - 8 } & 95 & 8.2 & 8.7 & 9,36 & 9,7 & 9,95 & 10,45 \\
\cline { 2 - 8 } & 100 & 8,7 & 9,2 & 9,7 & 9,95 & 10,2 & 10,7 \\
\hline
\end{tabular}

\subsection{Pengaruh Temperatur, dan Waktu hidrolisa terhadap Kadar Glukosa yang Dihasilkan dengan konsentrasi 2,5 N.}

Kadar glukosa adalah jumlah glukosa (gr/l) yang dihasilkan setelah proses hidrolisa terhadap lama temperatur operasi dengan konsentrasi katalis 2,5 $\mathrm{N}$ serta waktu yang digunakan. Pada penelitian ini bahan baku yang digunakan adalah pati kulit pisang kepok sebanyak 25 gr. Pengaruh temperatur dan waktu hidrolisa kadar glukosa yang dihasilkan pada berbagai variasi temperatur, yaitu temperatur $80^{\circ} \mathrm{C}, 85^{\circ} \mathrm{C}, 90^{\circ} \mathrm{C}, 95^{\circ} \mathrm{C}$ dan $100^{\circ} \mathrm{C}$, dengan konsentrasi katalis $2,5 \mathrm{~N}$ serta waktu 10, 20, 30, 40,50 dan 60 menit dapat dilihat pada Gambar 2.

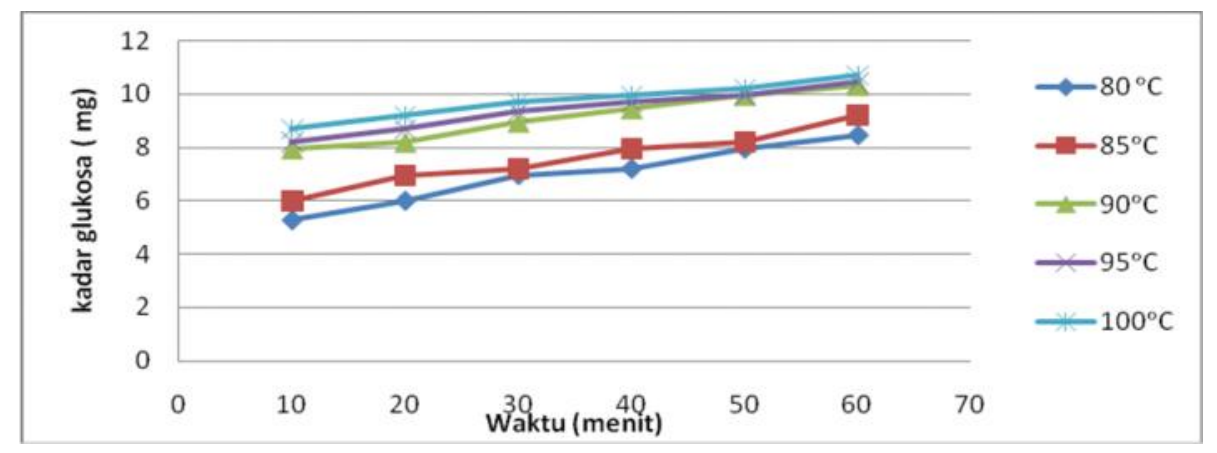

Gambar 2. Pengaruh temperatur dan waktu terhadap kadar glukosa 
Gambar 2 menunjukkan bahwa kadar glukosa tertinggi pada waktu 60 menit adalah pada temperatur $100^{\circ} \mathrm{Cdengan}$ kadar glukosa yaitu $10,7 \mathrm{mg} / \mathrm{ml}$. Dari gambar 4.2.1 di atas, terlihat bahwa kadar glukosa dipengaruhi oleh waktu. Semakin lama waktu operasi maka semakin banyak kadar glukosa, Hal ini disebabkan karena semakin lama waktu hidrolisa maka semakin banyak kadar glukosa yang terurai oleh katalis asam klorida sehingga menghasilkan kadar glukosa yang lebih banyak. Hal yang sama juga terjadi terhadap kenaikan temperatur operasi, semakin lama temperatur operasi maka kadar glukosa yang terbentuk juga semakin banyak (Levenspiel,1992).

\subsection{Konversi Pati dan Yield Menjadi Glukosa}

Data hasil penelitian untuk hasil Konversi, Yield menjadi Glukosa dapat dilihat pada Tabel 3 .

Tabel 3 Konversi, dan yield untuk 25 gr pati dalam $1500 \mathrm{ml}$ air pada setiap satuan waktu dengan konsentrasi HCL 2,5 N.

\begin{tabular}{|c|c|c|c|}
\hline Temperatur $\left({ }^{\circ} \mathrm{C}\right)$ & Waktu (menit) & Konversi (\%) & Yield (\%) \\
\hline \multirow{3}{*}{80} & 10 & 0,2582 & 0,2872 \\
& 20 & 0,2935 & 0,3264 \\
& 30 & 0,3404 & 0,3786 \\
& 40 & 0,3522 & 0,3917 \\
& 50 & 0,3888 & 0,4325 \\
& 60 & 0,4133 & 0,4597 \\
\hline \multirow{3}{*}{85} & 10 & 0,2935 & 0,3264 \\
& 20 & 0,3404 & 0,3786 \\
& 30 & 0,3522 & 0,3917 \\
& 40 & 0,3888 & 0,4325 \\
& 50 & 0,4011 & 0,4461 \\
& 60 & 0,4500 & 0,5005 \\
\hline 0 & 10 & 0,3888 & 0,4309 \\
& 20 & 0,4011 & 0,4439 \\
& 30 & 0,4378 & 0,5092 \\
& 40 & 0,4622 & 0,5277 \\
& 50 & 0,4867 & 0,5413 \\
\hline & 60 & 04578 & 0,5617 \\
\hline
\end{tabular}


Novi Sylvia dkk / Jurnal Teknologi Kimia Unimal 4 : 2 (November 2015) 51 - 65

\begin{tabular}{|c|c|c|c|}
\hline & 10 & 0,4011 & 0,4439 \\
& 20 & 0,4255 & 0,4700 \\
& 30 & 0,4578 & 0,4831 \\
& 40 & 0,4867 & 0,5141 \\
& 50 & 0,4867 & 0,5413 \\
& 60 & 0,5111 & 0,5685 \\
\hline \multirow{3}{*}{100} & 10 & 0,4255 & 0,4700 \\
& 20 & 0,4500 & 0,4961 \\
& 30 & 0,4744 & 0,5223 \\
& 40 & 0,4867 & 0,5413 \\
& 50 & 0,4989 & 0,5549 \\
\hline
\end{tabular}

\subsection{Pengaruh waktu terhadap konversi pada berbagai suhu}

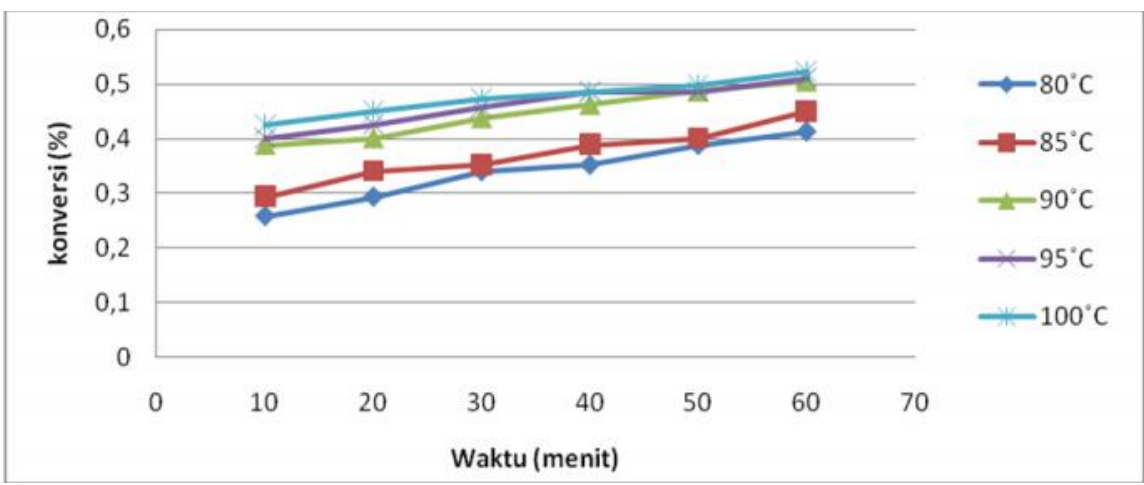

Gambar 3. Hubungan waktu dengan konversi pada berbagai suhu

Gambar 3 memperlihatkan konversi juga mengalami kenaikan. Konversi tertinggi pada temperatur $100^{\circ} \mathrm{C}$, waktu 60 menit adalah $0,5234 \%$. Pengaruh suhu terhadap kecepatan hidrolisa karbohidrat akan mengikuti persamaan Arhenius, bahwa semakin tinggi suhunya maka semakin tinggi konversi yang didapat, tetapi kalau suhu terlalu tinggi konversi yang diperoleh akan menurun. Hal ini disebabkan oleh adanya glukosa yang pecah menjadi arang, yang ditunjukkan oleh makin tuanya warna hasil. Disamping itu pada suhu yang tidak terlalu tinggi (tidak melebihi titik didih air), air sebagai zat penghidrolisa tetap berada pada fasa cair, sehingga terjadi kontak yang baik antara molekul-molekul serbuk kulit pisang dengan sebagian air. Dengan demikian reaksi dapat berjalan 
dengan baik. (Soebijanto,1989). Hubungan waktu dengan konversi pada berbagai suhu dalam dapat dilihat dalam Gambar 3.

\subsection{Pengaruh waktu terhadap yield pada berbagai suhu.}

Gambar 4 memperlihatkan nilai yield mengalami peningkatan seiring meningkatnya waktu operasi dari 10 menit sampai waktu 60 menit. Peningkatan nilai yield ini disebabkan karena tingginya konsentrasi katalisakan mempercepat berlangsungnya reaksi. Selain itu, dengan meningkatnya temperatur akan memperluas permukaan partikel-partikel zat bereaksi sehingga mempermudah terjadinya reaksi antara zat satu dengan zat lainnya(Levenspiel,1992). Berdasarkan Gambar 4 terlihat bahwa nilai yield terbaik pada waktu 60 menit didapat pada temperatur $100^{\circ} \mathrm{C}$ dengan yield yaitu sebanyak $0.5821 \%$. Hubungan waktu terhadap yield padaberbagaisuhudalambentukgrafik dapat dilihat pada Gambar 4.

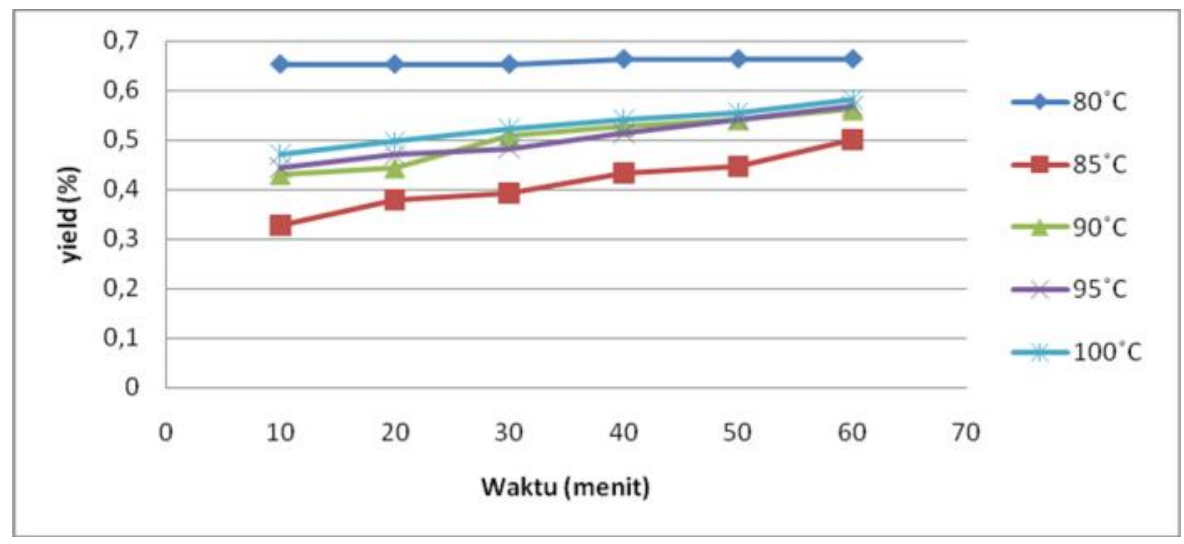

Gambar 4. Hubungan waktu dengan yield pada berbagai suhu

Hasil perhitungan dan data pengamatan di atas, untuk mengetahui orde reaksi dan nilai konstanta kecepatan reaksi hidolisis ini, dicoba orde satu semu. Maka dengan menggunakan persamaan kinetika akan diperoleh persamaan hubungan konversi $(\mathrm{x})$ dengan waktu $(\mathrm{t})$ yaitu $-\ln (1-\mathrm{x})=\mathrm{kt}$, sehingga apabila dibuat grafik hubungan $-\ln (1-\mathrm{x})$ dengan waktu (t), akan berupa garis lurus. Hasil 
perhitungan dapat dilihat pada table3 dan grafik dapat dilihat pada Gambar 5 sampai dengan Gambar 10.

Tabel 4 Hubungan antara -ln (1-x) dan waktu pada bebagai suhu

\begin{tabular}{|c|c|c|c|c|c|}
\hline \multirow{2}{*}{$\begin{array}{c}\text { Waktu, } \\
\text { menit }\end{array}$} & \multicolumn{5}{|c|}{-In (1-x) pada berbagai } \\
\hline & $8^{\circ} \mathrm{C}$ & $85^{\circ} \mathrm{C}$ & $9^{\circ} \mathrm{C}$ & $95^{\circ} \mathrm{C}$ & $100^{\circ} \mathrm{C}$ \\
\hline 10 & 0,298 & 0,347 & 0,492 & 0,512 & 0,554 \\
\hline 20 & 0,347 & 0,416 & 0,512 & 0,554 & 0,597 \\
\hline 30 & 0,416 & 0,434 & 0,579 & 0,612 & 0,643 \\
\hline 40 & 0,434 & 0,492 & 0,620 & 0,666 & 0,666 \\
\hline 50 & 0,492 & 0,512 & 0,666 & 0,666 & 0,691 \\
\hline 60 & 0,533 & 0,597 & 0,703 & 0,715 & 0,741 \\
\hline
\end{tabular}

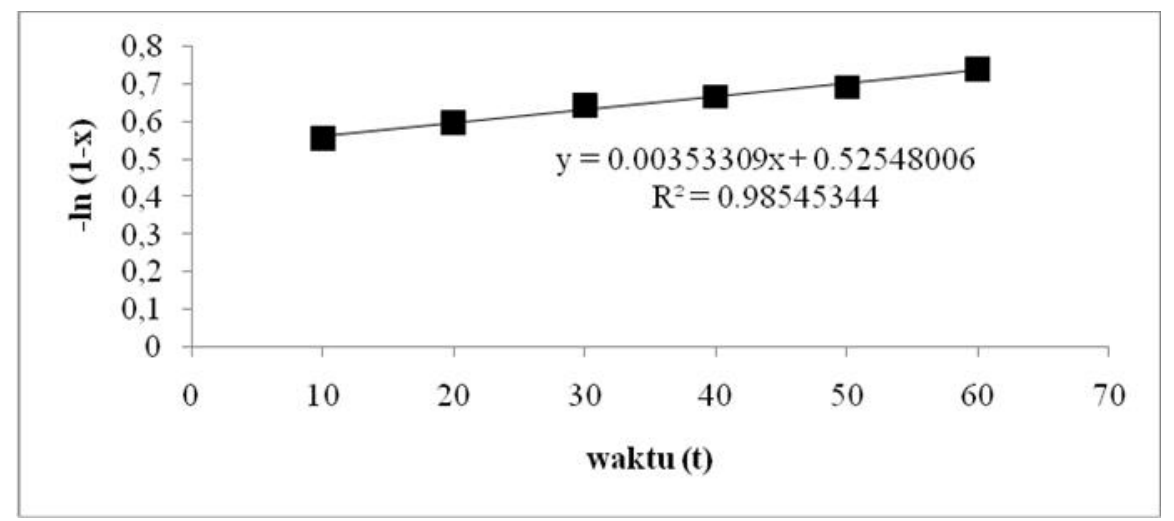

Gambar 5 Hubungan $-\ln (1-\mathrm{x})$ dengan waktu pada temperatur $80^{\circ} \mathrm{C}$

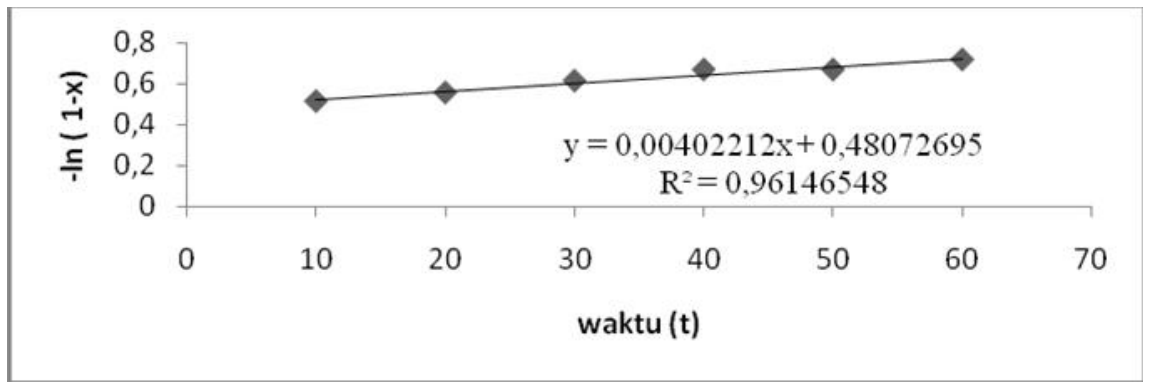

Gambar 6 Hubungan -ln(1-x) dengan waktu pada temperatur $85^{\circ} \mathrm{C}$ 
Novi Sylvia dkk / Jurnal Teknologi Kimia Unimal 4 : 2 (November 2015) 51 - 65

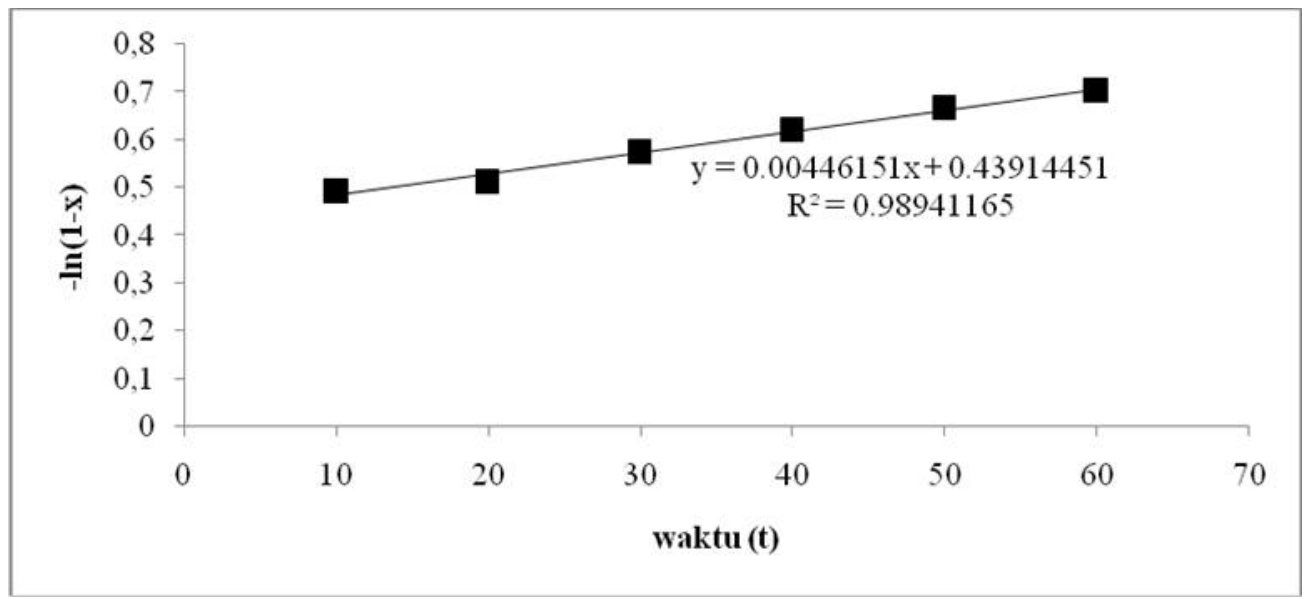

Gambar 7 Hubungan $-\ln (1-\mathrm{x})$ dengan waktu pada temperatur $90^{\circ} \mathrm{C}$

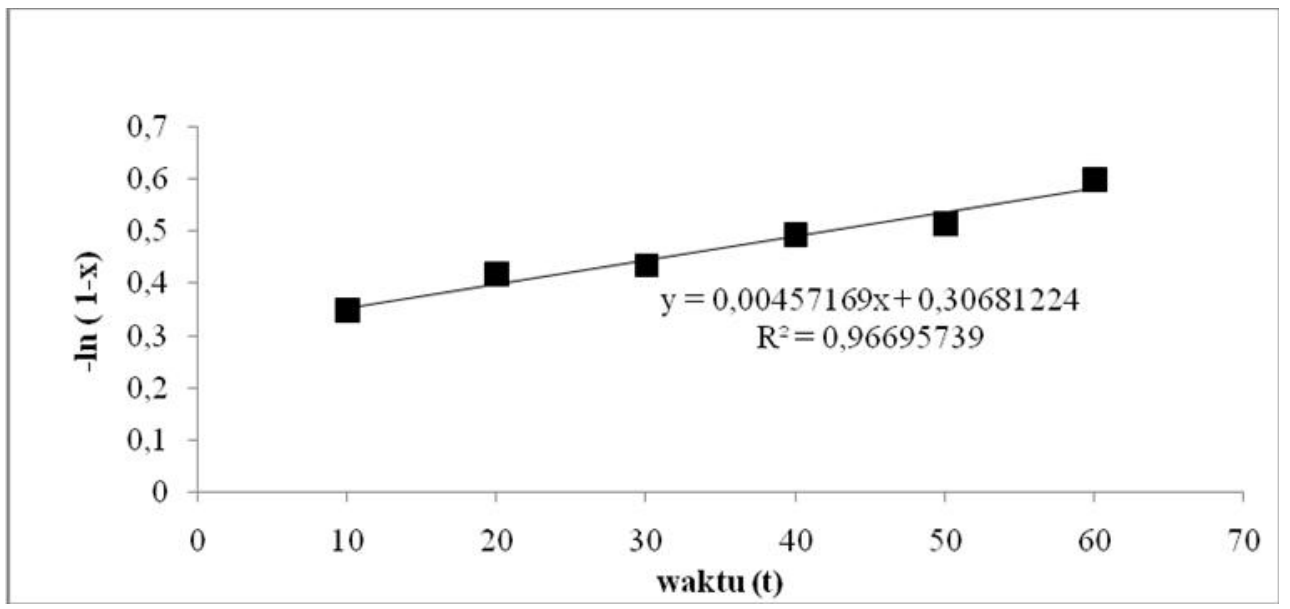

Gambar 8 Hubungan $-\ln (1-\mathrm{x})$ dengan waktu pada temperatur $95^{\circ} \mathrm{C}$

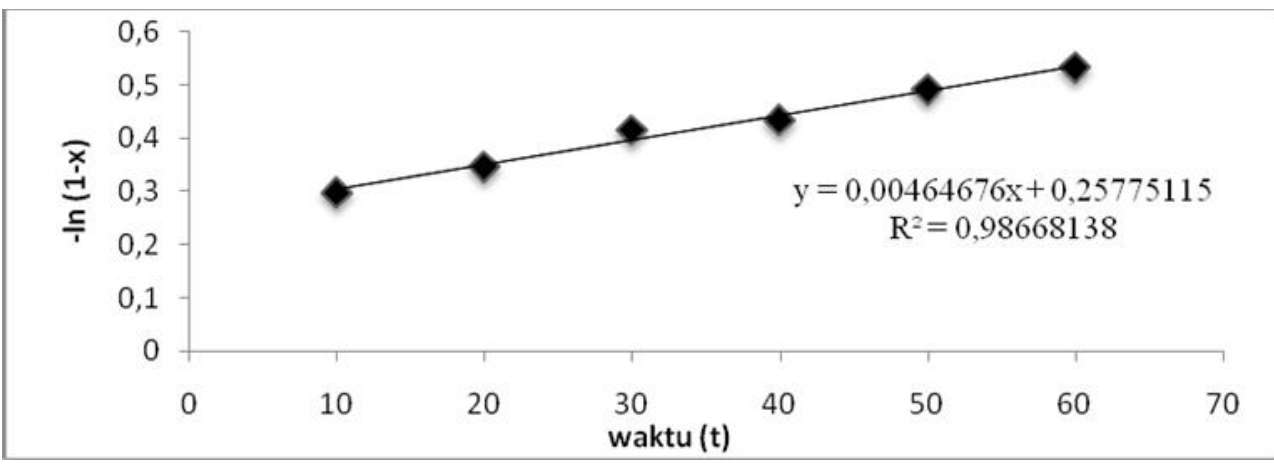

Gambar 9 Hubungan $-\ln (1-\mathrm{x})$ dengan waktu pada temperatur $100^{\circ} \mathrm{C}$ 
Dengan menggunakan persamaan $-\ln (1-\mathrm{x})$, dari gambar 4 sampai 8 terlihat bahwa reaksi orde satu semu. Dari grafik hubungan $-\ln (1-\mathrm{x})$ vs $\mathrm{t}$ mengikuti garis lurus. Nilai konstanta laju reaksi diperoleh dari slope pada persamaan $\mathrm{Y}=\mathrm{mx}$ +b.Hubungan konstanta laju reaksi dengan suhu ditunjukkan pada Tabel 4, yang terlihat bahwa semakin tinggi suhu maka semakin tinggi konstanta laju reaksi. Nilai konstanta laju reaksi dipengaruhi oleh sifat pereaksi dan suhu. Hal ini karena dengan naiknya suhu reaksi maka suplay energi untuk mengaktifkan pereaksi dan tumbukan antar pereaksi untuk menghasilkan reaksi akan bertambah sehingga produk yang dihasilkan akan lebih banyak (Herman, 2004). Sedangkan grafik hubungan antara suhu dan konstanta laju reaksi ditunjukkan pada Gambar 9.

Tabel 5 Pengaruh nilai Konstanta Kecepatan reaksi (1/menit) dengan suhu K pada berbagai suhu

\begin{tabular}{|c|l|c|c|}
\hline Suhu (K) & $(\mathbf{1} / \mathbf{T}) . \mathbf{1 0}^{\mathbf{3}}$ & $\mathbf{K}$ & $\ln \boldsymbol{k}$ \\
\hline 353 & 2.832 & 0.003533 & -5.6455 \\
\hline 358 & 2.793 & 0.004022 & -5.5159 \\
\hline 363 & 2.754 & 0.004461 & -5.4122 \\
\hline 368 & 2.712 & 0.004571 & -5.3867 \\
\hline 373 & 2.680 & 0.004645 & -5.3719 \\
\hline
\end{tabular}

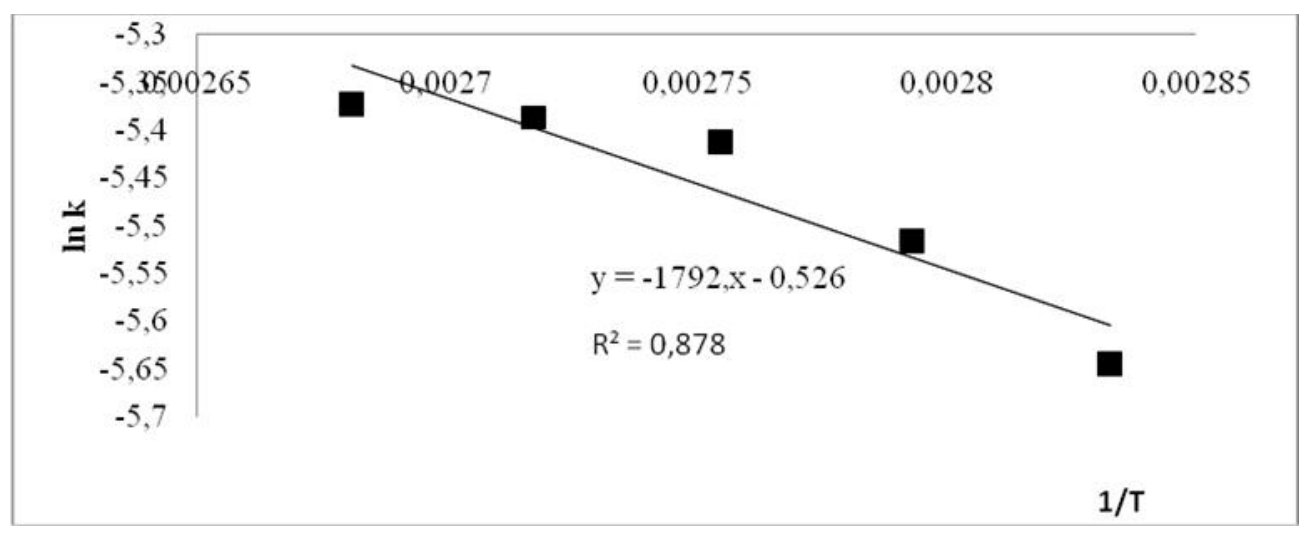

Gambar 10 Hubungan suhu dan konstanta laju reaksi

Harga konstanta pada tabel 5 diatas, maka akan dapat dihitung energi aktivasi. Melalui proses perhitungan dari grafik $\ln k$ dan 1/T tersebut diperoleh Ea $=14.715 .78 \mathrm{kj} / \mathrm{mol}$. Perubahan suhu umumnya mempengaruhi harga tetapan laju $k$, semakin tinggi suhu, konstanta kecepatan reaksi akan semakin besar dengan 
Novi Sylvia dkk / Jurnal Teknologi Kimia Unimal 4 : 2 (November 2015) 51 - 65

semakin berkurangnya energi aktivasi sehingga semakin mudah reaksi berlangsung (Levenspiel, 1972).

\section{Simpulan}

1. Hasil penelitian menunjukkan bahwa Semakin tinggi konsentrasi katalis asam klorida dan suhu hidrolisa maka kadar glukosa yang diperoleh akan semakin besar. Kadar glukosa terbesar adalah 10,7 mg diperoleh pada kondisi operasi $100^{\circ} \mathrm{Cpada}$ waktu 60 menit.

2. Semakin tinggi konsentrasi katalis dan semakin lama waktu operasi yang digunakan maka konversi reaksi semakin besar. Pada waktu yang sama, semakin tinggi suhu reaksi maka semakin besar pula hasil konversinya.

3. Reaksi hidrolisis kulit pisang kepok menghasilkan glukosa yang terjadi merupakan reaksi orde satu semu terhadap pati.

4. Pengaruh suhu terhadap konstantakecepatan reaksi mengikuti persamaan Arhenius dengan nilai konstanta kecepatan reaksi untuk temperatur 80, 85, 90, 95 dan $100^{\circ} \mathrm{C}$ adalah $=0.0033533,0.004022,0.004461,0.004571$ dan $0.004645 \mathrm{1} / \mathrm{menit}$ dengan energi aktivasi adalah $14.715,78 \mathrm{~J} / \mathrm{mol}$.

\section{Daftar Pustaka}

Enny, K., dan Andik, P. A., (2006), Pengaruh konsentrasi asam terhadap hidrolisa pati pisang. Ekullibrium, 5:8-12.

http://id.wikipedia.org/wiki/jagung, (2012).

Levenspiel, O., (1972), Chemical Reaction Engineering. Affilated East West Press DVT. Ltd. New Delhi.

Laila, (2012), Hidrolisa pati jagung menggunakan katalis asam sulfat, Laporan Skripsi.

Yuniwati, M., Ismayati, D., dan Kurniasih, (2011), Kinetika reaksi pati pisang tanduk dengan katalisator asam klorida, Jurnal Teknologi, 4:107-112.

Winarno, F.G dan M. Aman, 1981, Fisiologi Lepas Panen. Penerbit PT Sastra Hudaya, Jakarta. 